\title{
Self-reported priorities and resources of academic emergency physicians for the maintenance of clinical competence: a pilot study
}

\author{
Jonathan Sherbino, MD, MEd; ${ }^{* \dagger}$ Suneel Upadhye, MD, MSc; ${ }^{*}$ Andrew Worster, MD, MSc ${ }^{* \ddagger}$
}

\section{ABSTRACT}

Objectives: Medical licensing bodies and professional colleges require their members to maintain a broad spectrum of knowledge, skills and attitudes, which, when taken together, define a competent emergency physician (EP). The objectives of this pilot study were: 1) to determine the resources used by academic EPs to maintain competence and 2) to determine academic EPs' learning priorities.

Methods: Using a modified Dillman method, we surveyed EPs from 2 Canadian academic tertiary health sciences centres.

Results: Thirty-seven (68.5\%) of 54 EPs responded. Of those responding, $14(37.8 \%)$ attended grand rounds 3 times or more annually, and $34(91.7 \%)$ attended a medical conference or course at least once annually. Thirty-three (89.2\%) respondents read journal articles at least once monthly, with $22(59.5 \%)$ of those reading synopses of original articles. Twenty-three $(62.1 \%)$ received clinical updates via email, and $11(29.7 \%)$ subscribed to an audio journal or podcast of reviews of original research. Among the CanMEDS roles, Medical Expert, Scholar and Manager were selected as top professional development priorities by more than one-third of respondents. The topics that were not selected as priorities by respondents included patient communication and charting (Communicator); conflict resolution skills and teamwork abilities (Collaborator); advocate for patient and promote health in emergency department populations (Health Advocate) and ethical conflict resolution (Professional).

Conclusion: The results of this pilot study suggest that in order to maintain clinical competence in emergency medicine, traditional formats of professional development (e.g., grand rounds, print media and original research) are being substituted for independent study, online media and reviews of original research. This study also suggests a strong preference for Medical Expert topics, while Professional, Health Advocate, Collaborator and Communicator topics are not a reported priority for professional development.
Keywords: professional development, emergency physician, competence, CanMEDS

\section{RÉSUMÉ}

Objectifs : Les instances responsables de la délivrance des permis d'exercice de la médecine et les collèges professionnels exigent que leurs membres maintiennent une vaste gamme de connaissances, d'aptitudes et d'attitudes qui, ensemble, définissent les compétences en médecine d'urgence. Les objectifs de cette étude pilote étaient de 1) déterminer les ressources utilisées par les médecins d'urgence en milieu universitaire pour le maintien de leurs compétences et 2) déterminer leurs priorités en matière d'apprentissage.

Méthode : On a utilisé une version modifiée de la méthode Dillman pour interroger des médecins d'urgence de 2 centres hospitaliers universitaires de soins tertiaires.

Résultats : Trente-sept (68,5\%) médecins d'urgence sur 54 ont répondu. Parmi les répondants, 14 (37,8\%) ont dit participer à des conférences scientifiques 3 fois l'an ou plus, et $34(91,7 \%)$ ont participé à une conférence ou à une séance de formation médicale au moins une fois I'an. Trente-trois $(89,2 \%)$ des répondants ont affirmé lire des articles de revues scientifiques au moins une fois par mois, 22 (59,5\%) d'entre eux lisant des sommaires d'articles originaux. Vingttrois $(62,1 \%)$ ont dit recevoir des mises à jour cliniques par courriel et $11(29,7 \%)$ étaient abonnés à un journal audio ou à un service de baladodiffusion présentant des synthèses de recherches originales. Pour ce qui est des rôles CanMEDS, plus du tiers des répondants ont classé Expert médical, Érudit et Gestionnaire parmi leurs principales priorités en matière de formation professionnelle. Parmi les thèmes auxquels les répondants n'ont pas accordé la priorité, mentionnons la communication avec le patient et la tenue de dossiers (Communicateur), les habiletés en matière de résolution de conflit et de travail d'équipe (Collaborateur), la défense des intérêts des patients et la promotion de la santé dans les services d'urgence (Promoteur de

From the *Division of Emergency Medicine, McMaster University, Hamilton, Ont., the TRoyal College of Physicians and Surgeons of Canada, Ottawa, Ont., and the ‡Department of Clinical Epidemiology and Biostatistics, McMaster University, Hamilton, Ont.

Submitted Apr. 3, 2008; Revised Aug. 28, 2008; Accepted Aug. 28, 2008

This article has been peer reviewed.

CJEM 2009;11(3):230-4

$2302009 ; 11(3)$

$C J E M \bullet J C M U$ 
la santé) ainsi que la résolution des conflits d'ordre éthique (Professionnel).

Conclusion : Les résultats de cette étude pilote donnent à penser que pour assurer le maintien des compétences cliniques en médecine d'urgence, les activités classiques de perfectionnement professionnel (p. ex., conférences scientifiques, médias imprimés et recherche originale) sont délaissées au profit d'activités de formation individuelles, des médias en ligne et des synthèses de recherches originales. Cette étude indique également une nette préférence pour les thèmes relatifs à l'expertise médicale, tandis que le professionnalisme, la promotion de la santé, la collaboration et la communication n'ont pas reçu de statut prioritaire au chapitre du perfectionnement professionnel.

\section{INTRODUCTION}

Contemporary models of clinical competence in emergency medicine (EM) include broad, interconnected roles that collectively influence physician practice. The Royal College of Physicians and Surgeons of Canada uses a framework of 7 "CanMEDS Roles" that define competence: Medical Expert, Communicator, Collaborator, Manager, Health Advocate, Scholar and Professional. ${ }^{1}$ The College of Family Physicians of Canada uses a different framework, but captures the same ideas of competence within the 4 principles of family medicine: skilled clinician, community based, resource to a defined population and patient-physician relationship. ${ }^{2}$

Increasingly, physicians recognize that clinical competence is not static and must be maintained. The successful completion of an EM residency and initial certification by a professional college does not necessarily guarantee that an emergency physician (EP) will maintain clinical competence over the long course of their medical practice. ${ }^{3}$ Rather, licensing bodies and professional colleges require that, on an ongoing basis, physicians demonstrate their maintenance of a broad spectrum of knowledge, skills and attitudes that collectively define a competent EP. For example, in the United States, EPs are required to complete prescribed selflearning and self-assessment modules in combination with a recertification examination every 10 years. ${ }^{4}$

Research suggests that "need recognition," "research endeavor," "self-initiation," "technical skills" and "personal motivation" are features of successful lifelong learning by physicians. ${ }^{5}$ However, the traditional formats used for continuing education may not lead to success. Interactive, educational workshops seem to result in moderate changes in practice, while attending didactic lectures or presentations are unlikely to alter clinical practice. ${ }^{6}$ The most effective strategies for changing physician practice appear to be "audit and feedback," "academic outreach and detailing" and "clinical reminders." The least effective strategies include "didactic presentations" and "distribution of print materials." "

Faculty development and continuing medical educa- tion initiatives within the EM community may benefit from an understanding of the perceived needs of practising academic EPs to maintain competence. In anticipation of this project, we performed a MEDLINE literature review using the medical subject headings "emergency medicine" and "education, continuing." From 1966 to July 2008, no study was identified that addressed the maintenance of competence specific to EM.

The objectives of this pilot study were 2-fold. First, we sought to determine what resources were used by practising academic EPs to maintain competence. In an age of overwhelming information, we hypothesized that EPs rely heavily on second-order peer review (i.e., review articles or synopses of original research) to maintain a current practice. Second, we sought to determine the learning priorities of EPs in order to maintain their competence. Despite changes to postgraduate education and a broader conceptualization of clinical competence by society and licensing bodies, we hypothesized that practising EPs focus their professional development priorities toward the Medical Expert role with less emphasis on other competencies (e.g., Health Advocate).

\section{METHODS}

Between September 2007 and December 2007, all staff EPs from 2 Canadian academic tertiary hospital centres (Hamilton Health Sciences and St. Joseph's Hospital) were electronically surveyed using a modified Dillman method. ${ }^{8}$ An introductory letter was sent with subsequent follow-ups to nonresponders, according to prescribed time intervals. Part 1 of the survey addressed the resources used by practising EPs to maintain clinical competence. Part 2 addressed the professional development priorities of practising EPs. Participants scored 3 representative topics for each of the 7 CanMEDS Roles that inform clinical competence using a 7-point Likert scale.

Institutional research ethics board approval was granted from Hamilton Health Sciences/McMaster University Faculty of Health Sciences Research Ethics Board, and all respondents provided informed consent. 
Investigators were blind to all data until they were pooled by a research assistant for analysis using $\mathrm{Mi}$ crosoft Excel software (Microsoft Corp.).

\section{RESULTS}

Thirty-seven $(68.5 \%)$ of 54 EPs responded. Twentyseven $(73 \%)$ of the respondents were male. All respondents were board-certified in emergency medicine, 22 (59.5\%) by the College of Family Physicians of Canada (19 through residency training and 3 through practice eligibility certification). The remaining 15 (40.5\%) were residency-trained through The Royal College of Physicians and Surgeons of Canada. The average time in EM practice was 10.9 years.

\section{Part 1: resources}

The number of respondents attending grand rounds 3 or more times per year was $11(37.8 \%)$. The top reasons cited for nonattendance were conflicting clinical responsibilities $(n=29,78.4 \%)$, conflicting personal/ family responsibilities $(n=4,37.8 \%)$ and conflicting nonclinical professional responsibilities $(n=9,24.3 \%)$.

Nearly all respondents $(n=34,91.7 \%)$ attended a medical conference or course at least once per year, one-third of whom $(n=12,32.4 \%)$ regularly attended the original research tracks.

A majority of respondents $(n=33,89.2 \%)$ indicated they read journal articles at least monthly. The journals most frequently read included Canadian Journal of Emergency Medicine ( $n=26,70.2 \%)$, Canadian Medical Association Journal ( $n=26,70.2 \%)$, Annals of Emergency Medicine $(n=22,59.5 \%)$, New England Journal of Medicine $(n=12,32.4 \%)$ and Academic Emergency Medicine $(n=8,21.6 \%)$.

A majority of respondents $(n=22,59.5 \%)$ indicated they regularly read reviews or synopses of original articles with $62.2 \%(n=23)$ of respondents receiving these reviews by email. In addition, $59.5 \%(n=22)$ used websites to receive electronic updates on clinical practice. Finally, $29.7 \%(n=11)$ of respondents subscribed to an audio journal or podcast that provided reviews of original research.

\section{Part 2: priorities}

Table 1 shows the distribution of Likert scale responses for professional development priorities. The representative topics for Medical Expert, Scholar and Manager were selected by over one-third of respondents as high, very high or top priorities for maintaining clinical competence. The Medical Expert topics were scored the highest. When asked in a separate question to rank the top 3 priorities for maintaining clinical competence, topics not selected or chosen by only a single respondent included patient communication (Communicator), charting (Communicator), conflict resolution skills (Collaborator), teamwork abilities (Collaborator), advocate for patient (Health Advocate), promote health in emergency department populations (Health Advocate) and ethical conflict resolution (Professional).

\section{DISCUSSION}

Part 1 of this survey reveals 3 themes about the maintenance of clinical competence by academic EPs. First, traditional group learning (e.g., grand rounds) is attended by a minority of respondents, who stated that clinical, professional and family scheduling conflicts prevent them from attending. This finding is consistent with other EM studies, but differs from other medical specialties in which nonattendance is unrelated to professional or personal conflicts. ${ }^{9}$ The 24-hour, 365-day scheduling, which requires EPs present in the emergency department, does not mesh easily with traditional 9 am to 5 pm academic scheduling.

This result appears to conflict with the greater than $90 \%$ of respondents who stated that they attend medical conferences or courses that are traditionally didactic in nature. Yet, this inconsistency may reflect confounding variables relating to conference or course attendance, such as other benefits (e.g., networking and associated vacation) and the discrete time period of a conference or course.

The limited commitment to traditional group learning identified in this study should not necessarily be viewed as a negative finding. Two excellent systematic reviews have previously found a limited ability of traditional, didactic educational strategies to change physician practice. ${ }^{6,10}$ Continuing education strategies should broaden the focus and consider new instructional methods.

It is noteworthy that the majority of respondents reported that they use electronic media to maintain clinical competence and access medical literature. This finding appears to be unique to EM, as the most recent physician study we could identify indicated that online resources were not preferable to in-person conferences or print material for professional development. ${ }^{11} \mathrm{~A}$ recent study of paramedics indicated that using online 
teaching is favoured within emergency health services education. ${ }^{12}$

Finally, although the majority of respondents regularly read journals and attended conferences, the focus of these activities was not necessarily directed toward original research. We did not measure the proportion of EPs who routinely access original research or their level of comprehension and critical appraisal skills. However, our results indicate that the majority of respondents relied upon reviews or synopses of original research findings supplied by journals and electronic media.

The utility of second-order peer review (e.g., research synopses) has been previously described. ${ }^{13}$ The overwhelming availability of information (particularly in this electronic age), confusing decisions about the quality and relevance of research studies, and conflicting recommendations on appropriate clinical management make research review articles particularly attractive to busy clinicians. Our data suggests that academic EPs access synthesized information regarding original studies to maintain clinical competence.

Part 2 of this survey reveals that the professional development priorities of academic EPs are heavily focused on the Medical Expert, Scholar and Manager roles. Faculty development and continuing medical education initiatives may benefit from addressing the needs that result from this. However, further research is required to determine why the Communicator, Collaborator, Health Advocate and Professional roles were deemed less important.

To our knowledge, this is the first study to identify this variation in described priority in EM professional development. The data do not infer whether topics were rated poorly because of presumed competence in

\begin{tabular}{|c|c|c|c|c|c|c|c|}
\hline \multirow[b]{2}{*}{ CanMEDS role } & \multicolumn{7}{|c|}{$\%$ of respondents } \\
\hline & Not a priority & $\begin{array}{c}\text { Very low } \\
\text { priority }\end{array}$ & Low priority & $\begin{array}{l}\text { Medium } \\
\text { priority }\end{array}$ & High priority & $\begin{array}{l}\text { Very high } \\
\text { priority }\end{array}$ & Top priority \\
\hline \multicolumn{8}{|l|}{ Medical Expert } \\
\hline Current literature/research* & - & - & 2.9 & 2.9 & 40.0 & 37.1 & 17.1 \\
\hline Interpretation of diagnostic tests* & - & - & 8.6 & 25.7 & 45.7 & 17.1 & 2.9 \\
\hline Improve procedural skills* & 2.9 & - & 11.4 & 45.7 & 28.6 & 5.7 & 5.7 \\
\hline \multicolumn{8}{|l|}{ Scholar } \\
\hline Critical appraisal skills* & - & 8.6 & 31.4 & 22.9 & 31.4 & - & 5.7 \\
\hline Bedside teaching* & - & 5.7 & 11.4 & 37.1 & 37.1 & 8.6 & - \\
\hline Assess/feedback to learners* & - & - & 8.8 & 44.1 & 32.4 & 14.7 & - \\
\hline \multicolumn{8}{|l|}{ Manager } \\
\hline Billing strategies* & 8.6 & 2.9 & 20.0 & 28.6 & 22.9 & 11.4 & 5.7 \\
\hline Patient flow strategies* & 2.9 & 2.9 & 20.0 & 37.1 & 25.7 & 11.4 & - \\
\hline New information technology* & - & - & 8.6 & 40.0 & 34.3 & 17.1 & - \\
\hline \multicolumn{8}{|l|}{ Professional } \\
\hline Ethical conflict resolution & - & 11.4 & 25.7 & 45.7 & 14.3 & 2.9 & - \\
\hline Legal knowledge & - & 11.4 & 14.3 & 54.3 & 5.7 & 14.3 & - \\
\hline Balanced life & 2.9 & 17.1 & 11.4 & 37.1 & 20.0 & 8.6 & 2.9 \\
\hline \multicolumn{8}{|l|}{ Health Advocate } \\
\hline Advocate for patient & 2.9 & 2.9 & 25.7 & 48.6 & 17.1 & 2.9 & - \\
\hline Health in ED populations & 2.9 & 5.7 & 31.4 & 48.6 & 11.4 & - & - \\
\hline Change health care system & 5.9 & 17.6 & 20.6 & 23.5 & 26.5 & 2.9 & 2.9 \\
\hline \multicolumn{8}{|l|}{ Collaborator } \\
\hline Conflict resolution skills & 5.7 & 2.9 & 25.7 & 34.3 & 31.4 & - & - \\
\hline Teamwork abilities & 8.6 & 11.4 & 37.1 & 31.4 & 11.4 & - & - \\
\hline Leadership skills & 8.8 & 2.9 & 20.6 & 41.2 & 20.6 & 5.9 & - \\
\hline \multicolumn{8}{|l|}{ Communicator } \\
\hline Patient communication & 5.9 & 5.9 & 35.2 & 50.0 & 2.9 & - & - \\
\hline Charting & 2.9 & 14.3 & 22.9 & 45.7 & 11.4 & 2.9 & - \\
\hline Oral presentation skills & 5.7 & 2.9 & 25.7 & 34.3 & 31.4 & - & - \\
\hline
\end{tabular}


the role or because these roles are not deemed by EPs as important for competent clinical practice.

Of note, a recent study identified a similar trend related to the provision of feedback (and associated teaching) to EM residents by EPs. ${ }^{14}$ Similar to our results, this study found Medical Expert was heavily favoured while other competencies (e.g., Health Advocate) were discussed with significantly less frequency. Our findings suggest that academic EPs not only focus their resident feedback and education around topics skewed toward the Medical Expert role, but they also prioritize their own continuing education with the same predilection.

\section{Limitations}

Our study has 2 particular limitations. First, the small sample size and unique sample demographics limit the generalizability of our findings. The number of respondents and the academic environment of this pilot study prevent broad extrapolation of our findings to all practising EPs. Further research needs to be conducted to determine if our results reflect broader trends in EP maintenance of competence.

Second, although investigators were blinded and data was anonymized, it is possible that professional (i.e., social) desirability bias may have influenced the results. We suspect that the strong skew toward Medical Expert topics may be even stronger than our findings suggests. However, respondents may have felt compelled to represent themselves in a balanced fashion, identifying professionally desirable topics that are poorly attended in the study institutions.

\section{CONCLUSION}

The results of this pilot study add to the professional development literature in 2 principle areas. Our findings suggest that traditional formats of professional development (e.g., grand rounds, print media and original research) are being substituted for independent study, online media and reviews of original research to maintain clinical competence in EM. This study also suggests a strong predilection toward Medical Expert topics by academic EPs, while Professional, Health Advocate, Collaborator and Communicator topics are not a priority for professional development. Further research, using a larger and more diverse sample, is required to confirm these pilot findings.

Competing interests: None declared.

\section{REFERENCES}

1. CanMEDS 2005 Framework. Ottawa (ON): The Royal College of Physicians and Surgeons of Canada; 2005. Available: http://rcpsc.medical.org/canmeds/CanMEDS2005/index.php (accessed 2009 Mar 16).

2. Four principles of family medicine. Ottawa $(\mathrm{ON})$ : The College of Family Physicians of Canada. Available: www.cfpc.ca /English/cfpc/about\%20us/principles/default.asp?s=1 (accessed 2009 Apr 2).

3. Schrock JW, Cydulka RK. Lifelong learning. Emerg Med Clin North Am 2006;24:785-95.

4. McCabe JB. Emergency medicine continuous certification: Why, why now, why me? Ann Emerg Med 2002;40:342-6.

5. Hojat M, Nasca TJ, Erdmann JB, et al. An operational measure of physician lifelong learning: its development, components and preliminary psychometric data. Med Teach 2003; $25: 433-7$.

6. O'Brien MA, Freemantle N, Oxman AD, et al. Continuing education meetings and workshops: effects on professional practice and health care outcomes. Cochrane Database of Syst Rev 2001:CD003030

7. Bloom BS. Effects of continuing medical education on improving physician clinical care and patient health: a review of systematic reviews. Int 7 Technol Assess Health Care 2005;21: $380-5$.

8. Dillman DA. Mail and internet surveys: the tailored design method. 2nd ed. New York (NY): John Wiley \& Sons; 2000.

9. Bandiera GW, Morrison LJ. Emergency medicine teaching faculty perceptions about formal academic sessions: "What's in it for us? CJEM 2005;7:36-41.

10. Davis DA, Thomson MA, Oxman AD, et al. Changing physician performance: a systematic review of the effect of continuing medical education strategies. JAMA 1995;274: $700-5$.

11. Mamary EM, Charles P. On-site to on-line: barriers to the use of computers for continuing education. 7 Contin Educ Health Prof 2000;20:171-5.

12. Jerin JM, Rea TD. Web-based training for EMT continuing education. Prehosp Emerg Care 2005;9:333-7.

13. Haynes RB, Cotoi C, Holland J, et al. Second-order peer review of the medical literature for clinical practitioners. JAMA 2006;295:1801-8.

14. Bandiera G, Lendrum D. Daily encounter cards facilitate competency-based feedback while leniency bias persists. CJEM 2008;10:44-50.

Correspondence to: Dr. Jonathan Sherbino, Emergency Department, Hamilton Health Sciences, 237 Barton St. E., Hamilton ON L8L 2X2; sherbino@mcmaster.ca 